\title{
Recent Research on Ancient Israelite Education: A Bibliographic Essay
}

\begin{abstract}
This article presents a survey of the recent research which has been making significant developments concerning the question of scribal schools and education in ancient Israel, specifically in its recourse to the extra-biblical data provided by epigraphic remains and by the comparative potentials of the wider ancient world itself, and which has culminated in several monograph length treatments which have added substantially to the literature. It is intended to provide a brief critical examination of these works, in order to facilitate the reader to keep up with the latest views and opinions concerning such attempts. The literature will be treated chronologically, and the most substantial recent contribution (Carr 2011) will be subject to an extensive review, in aim of testing the conclusions here forwarded against the cumulative weight of the earlier findings. Finally, ways of moving forward within this field of problems will be suggested.
\end{abstract}

\section{Keywords}

Ancient Near East, ancient Israel, education, epigraphy, Hebrew Bible, inscriptions, literacy, oral theory, scribal culture, scribal schools, scribes, writing 


\section{Recent Research on Ancient Israelite Education: A Bibliographic Essay}

The formation of the Hebrew Bible has been the cornerstone of the critical study of this collection of books for as long as the subject has been a scholarly discipline, a field of problems which has often seen the writers of the biblical literature themselves become the object of scholarly concern, and which has crystallized into debates concerning the existence of scribal schools or systems of education in ancient Israel. Initially such questions were usually asked by exegetes whose primary interest was with the biblical 'wisdom' texts, so producing answers which tended to conflate 'literacy' as a cultural phenomenon with 'instruction', a societal function often implemented in a familial setting and not necessarily linked with literacy at all (e.g. Crenshaw 1985, 1998; and Heaton 1994); and reflected in standard reference works which viewed literacy in ancient Israel as a widespread phenomenon throughout the populace already in the eighth (e.g. Demsky 2007: 236) or seventh (e.g. Coogan 1993: 438) centuries BCE.

However, a branch of recent research has been making substantial developments in this area, specifically in its recourse to the extra-biblical data provided by epigraphic remains and by the comparative potentials of the wider ancient world itself, and culminating in several monograph length treatments which have added significantly to the literature. This article is intended to briefly review these works, in order to facilitate the reader to keep up with the latest views and opinions concerning such attempts.

\section{The context for a comparative approach to education in ancient Israel}

The trend to treat the problem of Israelite education according to the priority of the extra-biblical evidence largely follows in the methodological footsteps of Lemaire (1981), who in his recourse to both inscriptional evidence and analogies drawn from ancient Near Eastern sources made the first full attempt to provide a cumulative answer to the problem. In this and a later synthesis (2001), Lemaire described an extensive school system for monarchic Judah, inherited from Canaan, and developing from a specialized administrative scribal tradition in the early monarchy to a wider curriculum by means of which literacy was spread throughout the populace in the later monarchic period, based 
upon his reading of Deut. 6:6-9 and inferences drawn from inscriptions supposed to be the remainders of childish school exercises; in this curriculum, Lemaire saw the original context for the production, transmission and preservation of the Hebrew Bible.

It is apparent from this brief account of Lemaire's reconstruction — not only of scribal schools but indeed of a widespread system of education - that his analysis is dogged by the same tendency as the earlier studies built from wisdom literature to presuppose extensive literacy already in the monarchic period, an insight external to the comparative evidence which Lemaire nevertheless utilizes. Such lack of caution stems from a similar confusion in Lemaire's analysis to that of the previous studies, a failure to distinguish between evidence of writing and evidence of instruction in the biblical account: instruction that may well have been oral. Indeed, even when dealing with the written remains themselves, far from making the case that these should be read as the remnants of a system of schooling, the reality of such evidence is merely the acknowledgement of the existence of person(s) able to write to some extent. Speculation concerning that extent on the basis of Deut. 6:6-9 misunderstands the apotropaic, talismanic status afforded to writing in the instruction 'You shall write them on the doorposts of your house and on your gates', and so better explained by the needs of a largely oral culture, for which writing was understood as a numinous phenomenon.

Lemaire also faced sociological objections to his methodological premise, as most succinctly formulated by Golka (1983). Golka believed that the case for scribal schools in monarchic Israel had been 'built on sand' (1983: 257): the comparative element in Lemaire's reconstruction, he argued, failed to take into account the different developmental stages of Israelite and Egyptian political and cultural society in the tenth century BCE. At that time, Egypt was an advanced culture with two millennia of history behind her; Israel was at the very beginning of her political existence. Thus Golka proposed that comparative efforts must compare Israel's early monarchy to that of the Egyptian Old Kingdom - and here all education occurred in the home, therein refuting the claim of a school system in either stages of governmental development (1983: 264). While Golka's call for restraint was necessary in the face of Lemaire's excesses, it nevertheless rests upon an insufficient conception of the way states develop. We cannot suppose that the relatively simple Israelite culture developed at exactly the same rate of speed as the more complex Egyptian society. Sociological parallels between 
the two cultures, when explored with caution, may indeed provide valuable analysis possibilities. Nevertheless, the next monograph to explore literacy in ancient Israel took on such criticisms, and so Jamieson-Drake provided a reconstruction based purely upon archaeological data, without recourse to additional data gleaned from the biblical or extra-biblical literary sources (1991).

Compared to the excesses of Lemaire's reconstruction, Jamieson-Drake's is an exercise in caution. Instead of integrating the archaeological with the textual data (or indeed, with comparative materials), Jamieson-Drake proposed an analysis based solely upon archaeological remains. $\mathrm{He}$ endeavoured to discern the social variables necessary to sustain scribal activity, so the complexity of state administration in monarchic Judah. Therein he understood writing as an instrument of administrative control, and so explored the degree to which Israelite culture may be characterized as urban: writing correlates with the degree of control exercised by urban elites over agricultural producers; ' $[t]$ he greater the need for such control, the more likely the presence of full-time administrators to facilitate the exercise of control by the elite class' (1991: 35). In this context he examined a polythetic set of attributes which may be used to identify an increasingly stratified society, so (1) centralized administrative control; (2) social stratification; and (3) the existence of fulltime non-agricultural specialists; and the archaeological correlates to these variables, (i) settlement patterns; (ii) public works; and (iii) luxury items (1991: 37-40). The resultant analysis compelled a conclusion contra both Lemaire and the biblical account itself: a negative portrayal of an entity 'state' in tenth century Judah; not until the eighth century onward did Judah become a fully developed monarchic state, and even then, literacy did not spread far. Of the seven sites in the eighth and seventh centuries which contain material evidence of writing, all are discussed in terms of their dependence upon Jerusalem. Lachish, Arad and Meșad Hashavyahu were forts maintained by the Jerusalem regime; Gideon, Tell Beit Mirsim and En-gedi were entirely economically dependent upon Jerusalem; while Ramat Rahel was a royal suburb of Jerusalem. Hence Jamieson-Drake concludes that writing was associated with government, and so with a specialized administrative class of scribes trained in the capital (1991: 148).

Jameison-Drake's reconstruction is convincing, but nevertheless it is apparent that an account of scribal schools in the ancient world which depends upon only one of the available possibilities of 
analysis can only go so far, and indeed, Jamieson-Drake himself notes the importance of an archaeological study 'so that the written evidence is allowed to speak within an archaeologically established context' (1991: 9). Scholarship undertaken after this important work must keep the conclusions here found — of a Judaean scribal tradition beginning in Jerusalem from the eighth century onwards - at the forefront of their analyses, while fleshing out the workings of such a tradition with data gleaned also from the textual traditions. It is here we come to review such attempts. This literature will be treated chronologically, and the most substantial contribution, if only in its length if not in its methodological developments (Carr 2011), will be subject to an extensive review, in order to test the conclusions here forwarded against the cumulative weight of the earlier findings.

\section{Scribes and Schools (1998)}

Davies subtitled his attempt to provide this synthesis of textual and comparative data 'The Canonization of the Hebrew Scriptures' (1998) - and in this way his bedfellows are as much Childs and Sanders as they are Lemaire or Jamieson-Drake (although of course Davies is programmatically against what he deems to be the theological agenda of the former scholars). If it is initially unclear what all these might have to do with one another, Davies provides a convincing argument that canonization as a literary process should be viewed in close connection to a literate elite (so 'scribes') and their institutions ('schools'). However, once he moves away from this call for awareness of the socio-political factors of the canonization process to a description of the creation of the biblical canon itself, Davies's conclusions are much less compelling. In an earlier work (1992), Davies had argued that monarchic Israel and Judah were the creation of a later society which did not correspond to any actual entity present in Iron Age Palestine, and he set his study of canonization within the same conceptual framework: thus it was not 'ancient Israel' that produced a canon but rather a canon that produced ('created') ancient Israel (1998: 3). The resultant difficulties in the historical reconstruction and methodological programme advanced by such an agenda render Davies's reconstruction largely untenable: Davies favours a depiction of the canonization process in which the Persian period was the initial period of literary production for the Hebrew Bible (1998: 70), culminating with the Hasmonean period where canonization became something of a political act (1998: 72); the rabbis then, inherited a 
largely closed canon established foremost in this period. Davies underpins this with perceived analogies to the scribal practices of ancient Mesopotamia: by selecting texts and cataloguing them, these scribes were themselves engaged in acts of canonization (1998: 19-23).

The historical basis of this account falls short. Davies rejects the presupposition common since Wellhausen that the canonization of the Hebrew Bible began in 621 BCE with the 'discovery' of the book of Deuteronomy on account of his reading of the social and political contents therein described; instead he argues that this content reflects the realities of the fifth century BCE on such grounds as the central role afforded in Deuteronomy to the Levitical priests (1998: 92-99). This, along with other portions of Torah and Prophets, constitute the initial canonical material. Yet such a dating for Deuteronomy is in contention with topics covered (such as the monarchy passage, Deut. 17:15-20) and not covered (many of the key issues which affected the fledging Judaean community in Persian period Jerusalem, such as the destruction of the First Temple, the end of the Davidic line, or the role of Persia in world affairs) in the book itself; the ascription of the books of Ezra, Nehemiah, Chronicles and Deuteronomy to the same geographical and temporal locus seems unsustainable. Indeed, this is symptomatic of the tendency in Davies's account to truncate the period of literary formation behind the Hebrew Bible into a period of merely two and a half centuries, all of it authored in Jerusalem, and then canonized in a period shortly thereafter. This can be denied by even brief recourse to the heterogeneous literature of the Hebrew Bible; the language in which this literature was rendered is itself far from monolithic, ranging in orthography, morphology, vocabulary and syntax between archaic, standard and late periods (see e.g. Young 1993). Davies's reconstruction fails to adequately account for such features of the biblical literature in its historical outline.

Methodological problems also abound in Davies' analysis, specifically in regard to the comparative parallels which he calls upon. Davies builds upon the suggestion of Sarna (see e.g. 2007 [1971] for the most coherent statement of this) that Jewish canonization might ultimately derive from a Mesopotamian precedent, a so-called 'cuneiform canon'. Yet the application of such a term to cuneiform texts is itself controversial (Rochberg-Halton 1984). Indeed, Davies's use of the term is in general imprecise in its application, thus, for example, Barton's distinction between 'Scripture' as holy writings and 'canon' as an official decision to limit those writings is sorely lacking from 
Davies's discussion (Barton 1997); and the extent to which similarities exist between the 'canonization process' of the Bible over some two and a half centuries as Davies outlines, to the transmission of literary texts over thousands of years from the Sumerians to the Babylonians, to the Kassites, to the Assyrians, to the Chaldeans, to the Persians, is questionable. Crucially, according to Davies' dating, canonization began and concluded somewhere between 450-150 BCE, with the larger and most determinative period of this process to be found in the Hellenistic period: when Aramaic had replaced Akkadian as the lingua franca of the ancient Near East, and so at a time when cuneiform scribal practices at Jerusalem were most likely largely irrelevant. Surely by this time scribal influence on Jewish practice should be sought from Graeco-Hellenistic models (see e.g. Schams 1998), and not the much earlier Mesopotamian ones. In short, the conceptual framework in which Davies sets his study, and the resultant historical and methodological problems therein created, render this account largely insufficient in its attempt to understand the scribal tradition which may have underpinned the formation of the Hebrew Scriptures.

\section{How the Bible Became a Book (2004) and Writing on the Tablet of the Heart (2005)}

More compelling are the works of Schniedewind (2004) and Carr (2005), published in quick succession of each other, and especially successful when taken together. Schniedewind's approach is something of a corrective to the trend following Davies to over-emphasize the Persian and later periods as the most determinative time for the generation of the Hebrew Bible. Instead, building from and extending the work of Jamieson-Drake, Schniedewind concludes with Jamieson-Drake that the late eighth century provided the necessary conditions for the flourishing of scribal systems in Jerusalem. Following the military campaigns of Neo-Assyria and subsequent population influx from the Northern Kingdom and Judaean hill country, Hezekian scribes first began to write down oral traditions in order to integrate the traditions of the Northern refugees with those of the Southern kingdom (2004: 64). On the basis of the epigraphic evidence, Schniedewind then maps this largely temple- and court-based literacy as it apparently rapidly progressed in the seventh century to spread throughout the populace in the reign of King Josiah, a time when much of the Pentateuch was formed 
(2004: 127-28); by this account, far from being the most generative periods of literary creativity, the exilic and post-exilic periods were rather times of collection, editing and interpretation.

Schniedewind's proposals are largely convincing, based as they are upon a synthesis of all available evidence. His survey is excellent at providing internal reasons for why these Israelite traditions crystallized. Slightly less secure is his account of how these traditions formed, due in part to an insufficient understanding in his interpretation of the relationship of orality to textuality in the ancient world. Although Schniedewind is fully aware of the recent scholarship which has stressed a continuum between oral and literate modes of textual production, referring the reader to Niditch's account (1996) of this oral/literate continuum (Schniedewind 2004: 12), he nevertheless draws heavily on the work of scholars such as Goody (2000) and Ong (1998) which posited instead the now discredited idea (indeed, by Niditch herself, 1996: 1-7) of a sharp opposition between oral and literate communication in diachronic terms; thus in his theoretical aim to examine the tension between the spoken and written word as competing mediums of cultural and religious authority, Schniedewind tends also to exaggerate a tension between orality and literacy itself. This is most apparent in his reconstruction of an apparent expansion of literacy during the seventh century:

With the emergence of literacy and the flourishing of literature a textual revolution arose in the days of King Josiah. This was one of the most profound cultural revolutions in human history: the assertion of the orthodoxy of texts. As writing spread throughout Judaean society, literacy broke out of the confines of the closed scribal schools, the royal court, and the lofty temples... Basic literacy became commonplace, so much so that the illiterate could be socially stigmatized (Schniedewind 2004: 91).

This proposal is in stark contrast to the conclusion of other recent studies of literacy in the ancient world that no such society achieved literacy in these general terms; even the levels of literacy in ancient Greece, once thought to have yielded a rather larger literate population than most by virtue of the simplicity of the Greek alphabetic writing system, has been significantly revised (e.g. by Harris 1989). What needs further differentiation in Schniedewind's reconstruction is between the different sorts of literacy which one might be able to achieve in the ancient world. Implicitly at work here is 
the assumption that 'literacy' entails merely the provision of basic reading and writing skills; yet what we so often find in antique cultures is an intense focus upon the mastery of a given cultural tradition (so the Gilgamesh epic in Sumer and Akkad; Homer in Greece, etc.) in terms of Assman's description of a 'cultural text' (1996: 60-82). The scribal conservation of these cultural texts, often in an older language or script, is a different kind of literacy to writing for business purposes: so we may find a situation in which inscriptional remains such as ostraca attesting to the business use of literacy are found in one language (say, Schniedewind's Aramaic inscriptional finds), even as a small scribal elite continued to educate itself in, and even to expand, cultural texts (say, in Hebrew) - and as Schnedewind has himself has noted, in later periods of Jewish history Hebrew assumed a primarily ideological function (Schniedewind 1999: 235-52).

Such a portrayal of ancient literacy has been felicitously determined by Carr. Carr's major breakthrough in this context is his application of Niditch's study of orality in ancient Israel (1996) to the problem of Israelite literacy, a debt explicit in the very first pages of his book where he quotes Niditch's stinging attack on biblical scholarship as traditionally practised:

At the heart of documentary hypothesis... is the cut-and-paste image of an individual pictured like Emperor Claudius of the PBS series, having his various written sources laid out before him as he chooses this verse or that, includes this tale not that, edits, elaborates, all in a library setting... If the texts are leather, they may be heavy and need to be unrolled... If texts are papyrus, they are read held in the arm, one hand clasping or "supporting" the "bulk" of the scroll, while the other unrolls. Did the redactor need three colleagues to hold J, E, and P for him? Did each read the text out loud, and did he ask them to pause until he jotted down his selections, working like a secretary with three tapes dictated by the boss? (Carr 2005: 3, quoting Niditch 1996: 113).

Niditch rejects such anachronistic presuppositions - she writes in contrast to traditional conceptions of orality as a separate stage which predated the writing down of the biblical traditions, an approach which often accompanied the form criticism associated with Gunkel, and which alleged an oral stage 
of tradition behind the literary documents coterminous with a 'folk' mentality: and so artistic reformation at the stage of literary collection was necessary to mitigate the literary and intellectual limitations such a stage of formation would apparently entail (see e.g. Gunkel 1901). This evolutionary schema was promoted by the prevalent nineteenth century model which related cultural/structural simplicity to evolutionary priority, so Frazer could posit 'a ruder and earlier phase of the human mind, through which all the races of mankind have passed or are passing on their way to religion and science' (1993 [1890]: 56). In biblical scholarship this crystallized variously in terms of models concerned with primitive mentalities or corporate personalities, based on the opposition of pre-logical/logical mentality (e.g. Wheeler Robinson 1981 [1935]). Instead Niditch argues for the interrelationship of the predominantly oral world of ancient Israel with the rise of literacy during the time of the monarchies: the oral and written were concurrent and interacting in Israelite society (1998: 5). Indeed, she even attempts to identify degrees of orality within the preserved text of the Bible itself, via criteria such as formulaic language, repetition, epithets, referentiality and patterns of content, illustrated in her account (as a good student of Moore Cross might) by the visionEnthronement pattern (1998: 21-24); here her work is heavily dependent upon the methods first developed by Lord (1965) and Parry (1971) for the study of Homeric literature. (The Lord-Parry theory may be seen in the larger context of the shift from nineteenth century theorizing to the more synchronic intellectual paradigms of the twentieth century and their tendency to understand phenomena through the analysis of function and form: it is thus related to both structuralist and formalist models.) Although Niditch is not the first to draw upon the techniques of Parry and Lord to trace oral forms in the biblical text-Niditch herself has expressed her debt to the so-called Scandinavian school of biblical scholarship and its preoccupation with oral tradition (1998: 1), as represented primarily by Nyberg (1935), Engell (1945), and Nielsen (1954)—her account provides a more nuanced discussion than this previous scholarship due to its emphasis on an oral-written continuum, as opposed to the oral-written dichotomy which underpinned previous inquiries. Thus she proposes four models which might describe the formation of biblical literature: (1) the dictated or copied performance, so the prophetic tradition; (2) the pan-Israelite story, so Genesis through 2 Kings, 
transmitted in the fashion of Greek epic; (3) literary imitation of these two oral styles; and (4) the use of written sources for written composition, so the books of Chronicles (Niditch 1998: 117-129).

The identification of oral materials in a written text is far from simple, and the criteria which Niditch has built from the Lord-Parry theory are far from providing definitive cues from which such a study might be undertaken: as Niditch's third model recognises, supposed oral traits could be explained as examples of written imitation as well as the remains of oral composition. What is particularly interesting here is the emphasis which she places upon the interaction of orality and literacy in ancient cultures, even as literacy is introduced; and Carr's subsequent appropriation of this in his reconstruction of the Israelite scribal system. Instead of seeing this process as purely literary, Carr, drawing on Niditch, recognizes that this took place within a primarily oral culture. Crucial here is the idea of cultural texts as earlier defined, and reflected in the title of Carr's study itself: the emergence of the scribal profession engendered more than just the generation and transmission of texts. Rather it was an experience of 'educational enculturation'. Beyond merely the ability to read or write, literacy was the mastering of core texts 'by heart'. In this way, scribes were able to recall the tradition from memory, either to reproduce it in toto or to use it as the source for images and expressions when creating the new out of pastiches of the old. Thus texts were produced, not by copying from written documents as scholarship pre-Niditch might have supposed, but through dictation or recollection from memory in a continuum of written and oral mastery (Carr 2005: 4-14). Carr underpins this model with inferences gleaned from recent scholarship concerned with this process in ancient Mesopotamia, Egypt, Greece and the Hellenistic world, so to provide a convincing case for linking studies of the transmission and evolution of the biblical text with studies of literacy and education.

This takes a two-fold approach. On the one hand, focusing on transmission, Carr argues that the Bible should be seen as a product of scribal practices; on the other, looking at canon-formation, he argues that the Jewish canon emerged in the Hasmonean period out of resistance toward Hellenism, when the transmission of these earlier traditions crystallized into an authoritative document (2005: 253-72). Nowhere then, does Carr deal with the origins of the traditions themselves, but rather with their use in the educational setting: Carr provides the externals of the process by which curricula 
became canon; he does not provide specific case studies of what this might have entailed in the biblical literature, and indeed, there is little here from the Bible itself, as Carr himself recognizes (2005: 295). In this way, the studies of Carr and Schniedewind are best taken together and have so been treated in this survey of literature. While Schniedewind provides an excellent account of the internals of why the biblical literature was written, but misrepresents the relation between orality and literacy, Carr provides a corrective to this with a valuable discussion of the nuances of this relation in his account of the externals of the process by which this literature was transmitted. It is to subsequent scholarship which we must look to find a synthesis of both approaches.

\section{Scribal Culture and the Making of the Hebrew Bible (2007)}

So Karel van der Toorn (2007), who underpins his reconstruction of Israelite scribal culture with studies of two biblical documents, the books of Deuteronomy and Jeremiah. In his recourse to texts from both the Torah and Prophetic writings, van der Toorn supposes that these two books may thus be taken as ciphers for the understanding of the formation of the Hebrew Bible as a whole (2007: 7) though to what extent Deuteronomy is in any way typical of the production of Genesis through Numbers is rather tenuous; and, as elsewhere van der Toorn speculates that the scribes behind Jeremiah and Deuteronomy may have been one and the same (2007: 199), his analysis is rather more limited in this respect than he may wish to acknowledge. Van der Toorn's conclusions regarding the scribal culture of the ancient Near East differ markedly from his predecessors, and so it is worth recounting these before examining the consequences of this reconstruction for the perception of scribal dynamics in the formation of the biblical text itself; indeed, there is little interaction with the scholarly contributions of Carr or Schniedewind in van der Toorn's analysis, and his almost exclusive concentration upon the parallels afforded by Mesopotamian scribal culture differentiates his approach methodologically from these earlier studies and their concentration upon the oral/textual interplay (Niditch, Carr), or epigraphic context of Israelite scribes (Schniedewind).

The scant attention afforded to the epigraphic evidence from the Iron Age is perhaps symptomatic of the dual proposal with which van der Toorn starts his analysis, and which his interaction with the Mesopotamian and biblical data attempts to demonstrate: (1) that '[t]he scribes 
who manufactured the Bible were professional writers affiliated to the temple in Jerusalem' (2007: 1); and (2) that their scribal workshop was 'active in the period between 500 and 200 BCE' (2007: 2). Van der Toorn thus rejects the royal context in which prominent scholars such as Weinfeld (1972), Lipiński (1986) and Schniedewind (2004) have situated the biblical scribes with a strong claim: '[f]rom the end of the Kassite period onward, scribal education took place in temple schools' (van der Toorn 2007: 56). This is largely unprecedented: while few would deny that the temple was a context for scribalism in the ancient Near East, to deny the equal—perhaps greater-context of other elite institutions such as non-cultic portions of the royal administration simply does not do the heterogeneous biblical material justice, and moreover, it misrepresents the evidence. Even a brief recourse to general surveys concerning the locations of libraries and archives in the ancient Near East indicates that temples were not the primary sites for such institutions: Olof Pedersén (1998: 200-70), for example, has shown that only 36 of 127 archives in so-called official buildings were found in temple structures (while 91 were found in palaces). The principal evidence which van der Toorn cites from his survey of the Mesopotamian materials in favour of such a reconstruction, two letters which emphasize the importance of not teaching priestly lore (van der Toorn 2007: 56), show only that there was a stress among priestly groups on protecting the secrecy of their teachings, and not among scribalism as a whole.

The case for a post-exilic dating lies upon similarly questionable grounds. Schniedewind's outline of the social and historical context of Yehud (2004: 139-164) undermines the feasibility of situating much of the most generative stages of the formation of the Bible within a Persian context. Crucially, van der Toorn's analysis is in this respect subject to the same limitations as was that of Davies, who proposed a similarly late dating in his Scribes and Schools: both hang much of their conclusions upon Mesopotamian parallels, and so damaging the argument for a 500-200 BCE dating for the production of the biblical material; in any case, the scribal culture of the Persian and Hellenistic eras would demand far more attention than either van der Toorn or Davies gives it if such a dating is to be maintained.

As a consequence the case studies of Deuteronomy and Jeremiah, built as they are from such an insufficient theoretical starting point, yield surprising results. Deuteronomy, like the other biblical 
books, is given a temple setting, a conclusion outside of the text itself, which has little interest in matters of cult and deals primarily with social legislation; moreover this setting causes van der Toorn to overlook important textual cues from the book in order to maintain its priestly provenance, and so the treaty genre and well-known Neo-Assyrian parallels of Deuteronomy receive little mention (the treaty genre is of course a royal document prepared by royal scribes). Van der Toorn maintains that the current book of Deuteronomy is the last of four editions, beginning (1) with the document 'discovered' in the temple during the reign of Josiah, the Covenant Edition or Urdeuteronomium which incorporated early legal materials such as the Book of the Covenant; (2) a Torah Edition, which adds laws encompassing the role of the priests; (3) a History Edition, rewritten to serve as an introduction to a larger historical narrative; and (4) a Wisdom Edition, concerned less with covenant and more with the intellectual significance of Torah (2007: 152-166). These editions constituted revisions undertaken every forty years $(620,580,540$ and $500 \mathrm{BCE})$, when the papyrus of the previous version had worn out, presenting the priests with an opportunity to revise the materials in light of changed circumstance. This proposal requires that we accept several assumptions that seem largely unfeasible: through each stage, the book of Deuteronomy must have existed in a single master copy which was then expelled from circulation and abandoned upon the creation of the new expansion; each new expansion was itself afforded by the convenient tendency of scrolls to wear out precisely every forty years. Yet even if we are able to suspend our belief in order to maintain such problematic assumptions, van der Toorn's reconstruction simply does not do justice to the complex composition of Deuteronomy as determined over the last century of scholarship.

Van der Toorn's conclusion concerning the formation of the book of Jeremiah, that this resulted from a complex dialectic between prophet as person and prophet as the inspiration for the scribes who composed the writings in his name (2007: 182-188), is easier to accept - although at times this too is subject to some rather uncritical reflections. Baruch is professed to have been a temple scribe (2007: 185), while Jeremiah's own priestly background, established already in the superscription of the book which bears his name, remains unacknowledged. More convincing is his analysis of the apparently autobiographical 'confessions' of Jeremiah, which van der Toorn shows to be scribal allusions to earlier literature, especially the book of Psalms (2007: 189, 193). Nevertheless, 
the reuse of traditional material in traditional (oral) cultures is not a new discovery, and while van der Toorn should be credited for showing the workings of this in the mirror of Jeremiah, it is doubtful to what extent his book breaks any new ground following the more thorough and methodologically coherent achievements of Carr and Schniedewind.

The Invention of Hebrew (2009) and Writing and Literacy in the World of Ancient Israel (2010) With Sanders (2009) and Rollston's (2010, a synthesis of a large body of earlier articles: 2003, 2004, $2006,2008)$, the lens was once again firmly upon the use of epigraphic remains in the reconstruction of Israelite scribal culture. As Sanders builds many of his conclusions from Rollston's work, it is valuable to treat these studies together, though they have largely different emphases and dissimilar, though complementary, conclusions. Sanders' approach is unashamedly socio-political, based on his understanding that the Bible has 'a particular historical significance as political communication' (2009: 35). He thus attempts to understand the socio-politics of texts and text production in the ancient Levant, before employing these conclusions to explain the possibility of biblical composition in the Iron Age. Sanders takes his cue from the development of the atonement ritual at Israel which, along with Ugarit, was the only such rite to allow a principal role to the people themselves: concentration upon the people is thus for Sanders a specifically West Semitic political phenomenon (2009: 56-66). This is evident also in the transformation which he maps from the state-sponsored cuneiform texts of ancient Mesopotamia, to the vernacular of the late Bronze Age alphabetic writing of Ugarit, and later of Iron Age West Semitic (2009: 76-102): the introduction of alphabetic vernacular writing is indicative for Sanders of a focus upon local culture and people - and can even be constitutive of them. Thus biblical compositions are divinely voiced (rather than royally voiced) messages to the nation. Drawing upon the coherent body of Rollston's scholarship, Sanders then attempts to determine the authors of such a development. Based upon the precision and synchronic consistency of the epigraphic record, Rollston had argued that scribes must have undertaken formal training of some sorts; Sanders, owing to his reconstruction of a socio-political revolution accompanying the 'invention' of (written) Hebrew, accordingly attempts to situate this education within the people themselves (Sanders 2009: 125-29, drawing on Rollston 1999): '[t]hese studies 
were taught at scattered sites and communicated over time and distance through trade networks and family traditions,' by 'a geographically wide-ranging group of skilled artisans' - more specifically, 'potters or metalworkers' Sanders 2009: 131-133). Sanders's reconstruction of artisanal/craftsmanly scribalism, based as it is on (very) limited evidence and largely symptomatic of his socio-political assumptions, is essentially unproven and unprovable; Rollston's conclusion, based upon the same data, of a coterie of elites who received a formal and standardized scribal training (2010:112-13) is a more careful conclusion. Taken together, by showing (albeit with differing conclusions and methodological emphases) the need to posit a standardized scribal practice in the Iron Age due to the uniformity of orthography and palaeography of the epigraphic record, Sanders and Rollston have provided additional support for the conclusions and dating proposed by Schniedewind; and certainly at this point in our survey, something of a synthesis of Schniedewind and Carr's reconstructions, buttressed by the detailed epigraphic studies of Sanders and Rollston, seems the best explanation thus far offered for the phenomenon of texts and textual production in ancient Israel.

\section{The Formation of the Hebrew Bible (2011)}

In late 2011 Carr provided a second significant contribution to the problem of Israelite literacy and literature, his attempt to foreground the findings of his previous study (2005) with a specific biblical basis. The book is divided into three sections: the first (1) comprises methodological essays, the results of which are then applied to Carr's reconstruction of the formation of the Bible, in the second section (2) from the Hasmonean to the Neo-Assyrian periods; whereupon (3) he examines the literature of the early pre-exilic period in the final part of the book. This reconstruction is exhaustive, taking up some five-hundred pages, and so it is only possible here to offer an overview of the conclusions which Carr draws in his analysis. Thus I will briefly recount these, before providing a more detailed exploration of the methodological decisions which underpin these conclusions, as it is these decisions which are the crucial contribution of Carr's study, allowing him to subtitle his book as 'a new reconstruction'. 
The first section is essentially a recognition of the possibilities opened up by Writing on the Tablet of the Heart and the focus therein upon memorization and education, that interdisciplinary insights (as in Writing on the Tablet of the Heart, from the fields of Classics and folklore, but also from the cognitive sciences, so Bartlett 1932) might be utilized to better understand these phenomena within the production of biblical texts (2011: 14-17). Thus texts are transmitted, at least in part, through memorization; in the process of remembering and transmitting a given narrative, tradents reproduce the text with radical abbreviations, rationalizations and transformations (2011:25). In this way, literature transmitted through memory is distinct from literature produced by aural or graphic copying (which indeed reveals a large degree of verbatim repetition), as this contains instances of fluid intertextuality, and which Carr describes as 'memory variants' (2011: 17). Examples of intertextuality between the biblical books of Chronicles and Samuel-2 Kings, and in the book of Proverbs, are then subject to a detailed study in order to provide cumulative evidence to this conjecture, as these provide (in Carr's opinion) documented cases of memory variation.

The methodological implications of the memory variant model are damning for source-critical method as traditionally practiced. According to Carr, earlier layers of biblical tradition are not written 'in stone' but upon 'the shifting sands of memory' (2011: 36); attempts at reconstructing this prehistory are necessarily dictated by the impossibility to discern these shifting sands, and so what we as biblical scholars can ever hope to 'know' about the formation of the Hebrew Bible is seriously undermined. Having deconstructed traditional biblical criticism, Carr aims to provide more 'reachable goals' for the reconstruction of transmission history, and so forwards a programme which he characterizes as 'methodologically modest' (2011: 144-47). For Carr, methodological modesty entails that biblical criticism moves away from analysis of the minutiae of redactions and expansion within biblical texts, instead to analysis of the interrelationship between separate scrolls in the biblical tradition, and to larger strata, as with his study of variants between Chronicles and Samuel-2 Kings, and within Proverbs (2011: 148). The aim of such analysis cannot be the attribution of biblical books to a precise chronology, but rather the alignment of texts within 'broad periods', like the Persian or Neo-Babylonian (2011: 149). The following sections of Carr's book are the crystallization of the application of this method to the Hebrew Bible. 
Mapping the formation of biblical texts from back to front, Carr begins in section two with the Hasmonean period. Rather than sponsoring the creation of new works, this period is largely characterized by the 'defining, circumscribing, and possibly revising' of older traditions, sponsored by the Hasmonean monarchy, and primarily tied to the Jerusalem temple - with dissident groups such as that of Qumran opposing this delimited corpus (2011: 158). This is itself a result of developments in the Hellenistic era, when the temple had first begun to exercise great influence in the formation of the Bible, with the priests (and not the scribes) responsible for the copying and production of texts. To these priests Carr attributes the redacted portion of Qohelet, as well as the composition of Chronicles and portions of Esther and Daniel (2011: 195-201).

In the Persian period, it was the scribes who fulfilled this role. Noting that the Persian Empire alone escapes a negative portrayal in the Hebrew Bible, as a corollary Carr argues that the Bible was significantly shaped in this period, via the 'ongoing transmission, minor adaptation, and reconstrual of Pre-Persian-period compositions' (2011: 223; Carr's italics). Thus Persian period scribes combined and, crucially, reconceptualised the $\mathrm{P}$ and non-P Hexateuch in response to contemporary circumstance (2011: 219); with the focus upon Torah at the beginning of Joshua, the Psalter, and the end of Malachi, as well as the composition of Isaiah 56-66, Zachariah, Haggai and Ezra-Nehemiah also dated to this broad era $(2011: 206,224)$ : the Persian period was a time of both the rereading of older traditions, as well as the creation of some new ones.

The initial production of the $\mathrm{P}$ and non-P Hexateuch is to be found largely in the period of the Babylonian exile. Carr reconstructs a detailed history of this era, along with the period of NeoAssyrian domination, before attributing texts which fit in terms of their composition or reshaping to these historical profiles. In the Babylonian exile, the compositional process of the post-D Hexateuch 'combined at least three compositions: non-P Genesis material..., a pre-D Moses story, and a composition starting with Deuteronomy and including (at least) Joshua' (2011: 278; Carr's italics). The Priestly document originated as a 'counter-narrative' to the non-P document and is at times dependent upon non-P material (2011: 294-95)); like the post-D Hexateuch, this was itself probably not an original composition, but one connecting and expanding earlier traditions (2011:296). In this 
way, a post-D non-Priestly Hexateuch and an almost contemporary Priestly counterwork created Bible(s) for exiles.

Along with earlier studies which linked the significant expansion of Jerusalem in the eighth and particularly the seventh centuries to increased literary production (so Jamieson-Drake, Schniedewind), Carr dates the creation of much of this body of earlier tradition to the Neo-Assyrian period. Indeed, the shaping of the earlier traditions across Deuteronomy through 2 Kings is credited to the period of Neo-Assyrian domination, while potential reflections of Neo-Assyrian royal ideology are found in Genesis through Numbers as well (2011: 307-14). Portions of Isaiah, Amos, Hosea and Micah (eighth century), and Zephaniah and Jeremiah (seventh century) are also alleged to have originated in the Neo-Assyrian era (2011: 323-34), marking the late pre-exilic period as a time of much literate activity.

The early pre-exilic period is the focus of the final section. Contra scholars such as Jamieson-Drake (1991), Carr argues for a modest political centre formed already in Solomon's time, and built upon Davidic precedents (Carr 2011: 360-64). To this centre, Carr then ties portions of the Hebrew Bible, with surprising results. Arguing that some from the royal psalms should be thus attributed (2011: 389-402), Carr then makes the case for viewing Proverbs as a product of Israel's earliest scribal oralwritten curriculum, and from a time before the Torah of Moses had reached pre-eminence (2011: 405407). Carr builds his assertion from both extra-biblical and biblical evidence, arguing that Prov. 22:17-24:34 is a direct borrowing from the Egyptian wisdom instruction of Amenemope (2011: 408); while his contention that late pre-exilic texts such as Isa. 59:7, Deut. 19:14; 8:5, among others, are dependent upon Proverbial precedents substantiates the need for an early pre-exilic date for at least parts of Proverbs (2011: 413-425).

Finally, focusing upon Song of Songs, Carr attacks arguments for dating biblical books based upon criteria drawn from the diachronic development of the Hebrew language itself: if transmission history is as fluid as Carr maintains, then the language of a given textual tradition would likely have been contaminated by the scribal process. Thus attempts to date Songs by virtue of the dialectically late language variants found therein are methodologically flawed; instead, by positing an earlier 
dating, Carr is able to chronologically reconnect the book to love literature as found in the Mesopotamian, and particularly Egyptian, traditions (2011: 434).

The implications of Carr's reconstruction are far-reaching, and it is to scholars concerned with the individual texts that Carr connects and disconnects from their assumed historical settings that we must look to for an engaged response; in particular Carr's conclusions concerning the date of Proverbs and Song of Songs are challenging, and will likely provoke much scholarly ferment. My aim here is to problematize aspects of Carr's methodological programme, as it is this which underpins the argumentation of the work as a whole. Carr develops his 'memory variant' model by recourse to cases of intertextuality between the books of Chronicles and Samuel-2 Kings, and in the book of Proverbs; it is this methodological starting point which I find challenging in Carr's attempt, and which I believe undermines the cogency of his position as a whole.

Starting with Carr's use of the intertextuality between the books of Chronicles and Samuel-2 Kings, here, to put it simply, the concept of the memory variant is unconvincing to describe this relationship. The scribal context of the Chronicler is surely predominantly a writing culture, and the variants between the two books can more plausibly be explained by the Chronicler's theological reworking of a pre-existing written tradition, or by his recourse to an alternative written Vorlage than MT, rather than as examples of so-called memory variants stemming from the reproduction of his Vorlage through memory.

Carr's proposal is best evaluated by a close examination of the very examples of intertextual deviation employed by Carr himself in support of the memory variant thesis, $1 \mathrm{Chr}$. 13-16//2 Sam. 57.

1 Chr. 13:6 (MT) Then David and all Israel went up (ויעל)...

2 Sam. 6:2 (MT) Then David and all the people who were with him arose and set out (וילך)... 
Carr argues that the variants between 'went up' and 'arose and set out' are non-graphic and non-aural, and as such 'result from slight shifts in memory' (2011: 60). But the use of the vocabulary 'went up' (ע.ל.ה) can be better explained by the Chronicler's preference to express his liturgical conviction, an attitude which is explicit in the noun עלה, 'burnt offering', from the verb ע.ל.', 'to cause to ascend', hence 'burn' (see Brown, Driver and Briggs 1906: 748-750). At the close of Chronicles in 2 Chr. 36:23, the Chronicler added a postscript about the decree of Cyrus, who had allowed deportees to return to Jerusalem to rebuild the temple. Here the exhortation 'let him go up' contains a liturgical dimension, so that it is not just a physical journey of 'going up', but a liturgical attitude with song and sacrifice to 'go up' to the God of Heaven. In the case of $1 \mathrm{Chr}$. 13:6, the primary concern is the 'going up' of the ark of God to the tent of David; here too, the variant can be explained by the liturgical concern of the Chronicler.

Another example utilized by Carr is as follows:

1 Chr. 13:9 (MT) Uzzah reached out his hand to hold the ark
2 Sam. 6:6 (MT)
UQSam ${ }^{\text {a }}$
LXX

Carr again argues that the variants between 'to hold the ark' and 'he held it' are memory variants (Carr 2011: 60). However, this ignores alternative reasons which could also provide a plausible explanation for the variation. As evidenced above, 4QSam ${ }^{a}, \mathrm{LXX}$, and $1 \mathrm{Chr}$. 13:9 all provide the reading of 'his hand' against 2 Sam. 6:6. This likely indicates that the Chronicler relied on a Vorlage other than that represented in MT, and so the variant is better classified as a deviation of Vorlage rather than as a memory variant. Moreover, while $1 \mathrm{Chr}$. 13:9 uses the infinitive construct of 'hold', 2 Sam 6:6 prefers the waw consecutive: the Chronicler stresses the intention of Uzzah, while 2 Sam. 6:6 depicts the actual action itself. For the Chronicler, for whom the holiness of the ark was critical, even the intention of defiling the ark is unacceptable. This variation thus seems more likely to stem from ideological concerns, and not from insufficiency in memory. 
Carr also utilizes the further example of $1 \mathrm{Chr} .21: 16$, where his argumentation rests upon the reconstruction of $4 \mathrm{QSam}{ }^{\mathrm{a}}$, and the apparent memory variants produced by the author of this work:

1 Chr. 21:16 (MT) Then David raised his eyes and he saw the angel of YHWH standing between the earth and heaven, his drawn sword in his hand stretched over Jerusalem: David and the elders clothed with sackcloth fell on their faces.

2 Sam. 24:16-17 (MT) The angel of YHWH was at the threshing floor of Arunah the Jebusite. Then David spoke to YHWH when he saw the angel of God who was striking down the people.

4QSam ${ }^{\mathrm{a}} \quad$ The angel of YHWH was standing by the threshing floor of Arunah the Jenusite. [David] rai[sed his eyes and saw the angel of YHWH standing bet]ween earth and [heav]en; [his] drawn sword was in his hand [stretched out toward Jerusalem. David and the elders, cover]ed [in sackclo]th, [fell down on] their face]s.

Carr rightly observes that $4 \mathrm{QSam}{ }^{\mathrm{a}}$ is a harmonization towards Chronicles, but he goes on to conclude that this was a harmonization reproduced from memory (2011: 61). Yet 4QSam ${ }^{\mathrm{a}}$ is in this verse fragmentary in the extreme, and its reconstruction remains hypothetical in nature. The fragments themselves are largely verbatim identical with Chronicles, and only by his reconstruction is Carr able to show memory variants: it seems unlikely that here we have the incontestable proof which Carr is seeking.

The examples taken from Carr's hypothesis may indeed be explained by his model of memory variants - but they can also be explained both by the theological conviction of the Chronicler, or by the employment of a different Vorlage at the Chronicler's disposal. To favour the concept of memory variants for their explanation, as Carr does, requires further explanation than Carr is able to provide. Indeed, the memory variant explanation seems at odds with the literate context which is apparently recalled by the books of Chronicles. In our assessment of Writing on the Tablet of the Heart, it was noted that Carr owed a great debt to Niditch's Oral World and Written Word, and indeed 
it is here, in this earlier work, where perhaps the best rebuttal of Carr's use of Chronicles may be found:

Is it quite possible the Chronicler's source was quite set in memory...? [...] [T] he exact shaping of language between the Deuteronomistic History and 1 and 2 Chronicles makes less probable such a process in the work of the Chronicler. Rather in a more modern style literacy, 1 and 2 Chronicles transmits a written source. [...] [H]e uses verbatim written material (Niditch 1996: 129).

Such a claim is not without reason. The Chronicler explicitly states at various locations of his text that he is employing sources and annals, so 'the Chronicles of Samuel the seer', 'the Chronicles of Nathan the prophet', and 'Chronicles of Gad the seer' (1 Chr. 29:29), 'the prophecy of Ahijah the Shilonit', and 'the visions of Jedo the seer' (2 Chr. 9:29), 'the Chronicles of Shemaiah the prophet and Iddo the seer' (2 Chr. 12:15), and 'the history of the prophet Iddo' (2 Chr. 13:22), among others, are all variously evoked as sources from which the Chronicler had access; that 'Isaiah the prophet the son of Amos wrote' his source (2 Chr. 26:22; 32:32) explicitly refers this to be a written document.

Indeed, such was the written context of the Chronicler that he anachronistically imposed his concept of literacy into his depiction of Israel's past. For instance, though Elijah did not write oracles in the Deuteronomistic History, the Chronicler has him write a letter to confront the king of Judah (2 Chr. 21:11-15). Hezekiah sends couriers to dispatch letters to invite 'all Israel' to celebrate Passover in Jerusalem in 2 Chr. 30:6-9, an act not represented in the book of Kings. This reflects an understanding of literacy in the Second Temple period, where the scribal enterprise was much more developed than in the earlier period (see Schams 1998). The writing scribal culture of the Chronicler undermines the possibility of memory variants in the case of the intertextuality between Chronicles and Samuel-2 Kings.

While the literate scribal context of the Second Temple Period book of Chronicles denies the cogency of the application of the memory variant hypothesis in this instance, the apparently earlier exampleat least, according to Carr's reconstruction — of intertextuality within the book of Proverbs may, for 
this reason, appear better suited to such an analysis. Yet here too, Carr fails to provide adequate reasoning for why an explanation of memory variation should be privileged above other plausible possibilities. At a recent Old Testament Senior Seminar at the Faculty of Theology and Religion of Oxford University ('Literacy and Linguistic Matters in the Book of Proverbs', $12^{\text {th }}$ November 2012), Rendsburg felicitously made this point. Though noting that there are over one-hundred parallel verses in the book of Proverbs (see e.g. Snell 1993), Rendsburg chose the following examples of repetition with variation to best illustrate his argument:

Prov. 1:8 My son, heed the discipline of your father, and do not forsake the instruction of your mother

Prov. 6:20 My son, keep the commandment of your father; do not forsake the instruction of your mother

Prov. 2:16 It will save you from the strange woman, from the alien woman whose talk is smooth Prov. 7:5 She will guard you from a strange woman, from an alien woman whose talk is smooth

Prov. 20:16 Seize his garment (לקח־בגדו), for he stood surety for another; take it as a pledge [for he stood surety] for an unfamiliar woman

Prov. 27:13 Seize his garment (קח־בגדו), for he stood surety for another; take it as a pledge [for he $\quad$ stood surety] for an unfamiliar woman

Prov. 21:9 Dwelling (לשבת) in the corner of a roof is better than a contentious wife in a spacious house

Prov. 25:24 Dwelling (שבת) in the corner of a roof is better than a contentious wife in a spacious house 
Utilizing these samples, Rendsburg developed an understanding of textual variation in Proverbs to be an illustration of conscious editorial strategy: according to his interpretation, the atypical version of these twice-told traditional proverbs occurs first, suggesting a literary technique of de-familiarization followed by re-familiarization of the tradition. Indeed, not one of these one-hundred parallel verses in Proverbs provides exactly the same reading. To attribute this to poor memory simply does not do the literary art of the ancient Israelite scribe justice - as Rendsburg points out, surely their memories were better than that? Instead Rendsburg prefers to see these variants themselves as examples of literary art, and finds support for such an understanding in Heim's reading of 'variant repetition in Proverbs as a conscious, ubiquitous editorial strategy' (Heim 2011: 535).

What Rendsburg's critique of Carr illustrates is the long acknowledged difficulty of identifying oral material in a written text. While Carr's variants may well example the features of texts composed from memory, these features may also be explained as techniques of literate strategy. Indeed, in the case of Chronicles, where we have evidence that this was a text produced on the literate end of the oral-written continuum, the explanation in terms of literate strategy seems the more appropriate solution. Here Carr could find himself accused of treating the biblical material as a monolithic category. While this work sought to rectify the distinct lack of biblical material utilized in his earlier study (2005), Carr findings here may nonetheless be subject to the critique that he merely appropriates biblical materials in an a priori attempt to legitimate his foregone conclusions. Thus, though thorough, The Formation of the Hebrew Bible has not yet fulfilled the possibilities opened up by Schniedewind's How the Bible Became a Book, or Carr's Writing on the Tablet of the Heart, to provide a nuanced analysis of the role of scribal culture in the production of the Hebrew Bible.

\section{Conclusions}

As is evident from the above survey, this author finds something of a synthesis of the work of Schniedewind (2004) and Carr (2005) as the most comprehensive explanation yet offered to the question of education in ancient Israel. Further studies must take these works into account, but in order to move beyond this existing scholarship additional differentiation concerning literacy in ancient Israel must be made: (1) As the analysis of Carr (2011) developed above sought to show, 
some biblical texts are more 'literate' than others. If a study wishes to treat the formation of the Hebrew Bible as a whole, individual books must be carefully evaluated and placed on the spectrum of orality-literacy, in order to ascertain their suitability for the sort of analysis Carr et al. are proposing. To treat all biblical books under such a topos does not do justice to the manifold literary forms present in the biblical text. (2) Appeals to the existence of a Mesopotamian style scribalism in ancient Israel often presuppose that scribes in eighth or seventh century Judah were literate in Akkadian. While the scribes of the Middle and Late Bronze Age Canaanite city-states were able to read and write a form of Akkadian (e.g., the Amarna letters), is evident that this tradition of cuneiform literacy did not survive the beginning of the Iron Age. A small number of cuneiform texts have been discovered in Israel and Judah (Horowitz, Oshima and Sanders 2002), but an argument from this material would constitute a liberal interpretation of meagre evidence. Further study must consider the possibility of bilingualism at Israel, or the use of Aramaic as a bridge between the Akkadian and Hebrew traditions (on the importance of Aramaic in the Neo-Assyrian empire at this time, see Tadmor 1991). (3) If Carr's concept of the memory variant is to become a convincing criterion by which the formation of the Hebrew Bible can be understood, then a more substantial case will have to be made in order that we prefer this - and not any other - explanation as the best way to understand the production of ancient texts. The examples provided by Chronicles and Proverbs simply do not achieve this. (4) In this context, it is important to recognise that while contemporary biblical scholarship has increasingly focused upon the literate scribal elites of Israel and Judah, as Carr has recognized, this actually opens up the perspective by which the theory of oral composition may be brought into play, and so the possibility that models drawn from educational studies might here be valuable. Carr employed Bartlett's study of memory and memorization (1932) in his 'memory variant' theory, and while this author finds his ensuing conclusions largely unconvincing, the resultant possibilities for analysis which such a methodologically interdisciplinary programme might herald are indeed very much welcomed. The utilization of more current scholarship than that of Bartlett from the field of educational and cognitive research, perhaps from studies concerned with reading, memorization and literacy, may yet provide a firmer, more empirical basis for speaking about these matters in the ancient Hebrew world than has hitherto been possible. 


\section{Bibliography}

\section{Assmann, J.}

1996 'Kulturelle und literarische Texte', in A, Loprieno (ed.) Ancient Egyptian Literature: History and Forms (Leiden: Brill) 60-82.

Bartlett, F.C.

1932 Remembering: A Study in Experimental and Social Psychology (Cambridge; New York: Cambridge University Press)

Barton, J.

1997 Holy Writings, Sacred Text: The Canon in Early Christianity (Louisville, Ky.:

Westminster John Knox Press).

Brown, F., S.R. Driver, and C.A. Briggs

1906 A Hebrew and English Lexicon of the Old Testament (Peabody, MA.: Hendrickson Publishers).

Carr, D.M.

2005 Writing on the Tablet of the Heart: Origins of Scripture and Literature (Oxford: Oxford University Press).

2011 The Formation of the Hebrew Bible: A New Reconstruction (Oxford: Oxford University Press).

Coogan, M.D 
1993 'Literacy in Ancient Israel', in B.M. Metzger and M.D. Coogan (eds.) The Oxford Companion to the Bible (New York: Oxford University Press) 438.

Crenshaw, J.L.

1985 'Education in Ancient Israel', JBL 104: 601-615.

1998 Education in Ancient Israel: Across the Deadening Silence (New York: Doubleday).

Davies, P.R.

1992 In Search of 'Ancient Israel': A Study in Biblical Origins (JSOTSup, 148; Sheffield: JSOT Press).

1998 Scribes and Schools: The Canonization of the Hebrew Scriptures (Louisville, Ky.: Westminster John Knox Press).

Demsky, A.

2007 'Writing', in M. Berenbaum and F. Skolnik (eds.) Encyclopaedia Judaica (Detroit: Macmillan Reference USA, 2nd edn [1971]) 21: 235-46.

Engell, I.

1945 Gamla Testamentet: En traditionshistorisk inledning (Stockholm: Svenska Kyrkans Diakonistyrelses Bokförlag).

Frazer, J.

1993 The Golden Bough (repr.; Hertfordshire: Wordsworth Editions Limited [1890]).

Golka, F.W. 
1983 'Die Israelitische Weisheitsschule oder 'des Kaisers neue Kleider', VT 33: 257-70.

Goody, J.

2000 The Power of the Written Tradition (Washington, D.C.: Smithsonian Institution Press).

Gunkel, H.

1901 Genesis übersetzt und erklärt (Gottingen: Vandenhoeck \& Ruprecht).

Harris, W.V.

1989 Ancient Literacy (Cambridge, Ma.: Harvard University Press).

Heaton, E.W.

1994 The School Tradition of the Old Testament (Oxford: Oxford University Press).

Heim, K.M.

2011 Poetic Imagination in Proverbs: Variant Repetitions and the Nature of Poetry (Winona Lake, Ind.: Eisenbrauns).

Horowitz, W., Oshima T., and Sanders, S.L.

2002 Cuneiform in Canaan: Cuneiform Sources from the Land of Israel in Ancient Times (Jerusalem: Israel Exploration Society).

Jamieson-Drake, D.J.

1991 Scribes and Schools in Monarchic Judah: A Socio-Archaeological Approach (JSOTSup, 109; Sheffield: Almond Press).

Lemaire, A. 
1981 Les écoles et la formation de la Bible dans l'ancien Israël (OBO, 39; Fribourg: Éditions Universitaires; Göttingen: Vandenhoeck \& Ruprecht).

2001 'Schools and Literacy in Ancient Israel and Early Judaism', in L. Perdue (ed.) The Blackwell Companion to the Hebrew Bible (trans. A. Niang; Oxford: Blackwell) 207-12.

Lipiński, E.

1988 'Royal and State Scribes in Ancient Jerusalem', in J.A. Emerton (ed.) Congress Volume Jerusalem 1986 (VTSup, 40; Leiden: Brill) 157-64.

Niditch, S.

1996 Oral World and Written Word: Ancient Israelite Literature (Louisville, Ky.: Westminster John Knox).

Nielsen, E.

1954 Oral Tradition (SBT, 11; London: SCM Press).

Nyberg, $\mathrm{H}$.

1935 Studien zum Hoseabuche: zugleich ein Beitrag zur Klärung des Problems der Alttestamentlichen Textkritik (UUÅ, 6; Uppsala: A.B. Lundequistska).

Ong, W.

1988 Orality and Literacy: The Technologizing of the Word (New York: Metheun).

Pedersén, $\mathrm{O}$.

1998 Archives and Libraries in the Ancient Near East 1500-300 B.C. (Bethesda: CDL Press). 
Rendsburg, G.A.

2012 'Literacy and Linguistic Matters in the Book of Proverbs' (paper delivered at the Old Testament Senior Seminar of the Faculty of Theology and Religion, Oxford University).

Rochberg-Halton, F.

1984 'Canonicity in Cuneiform Texts', JCS 36: 127-44.

Rollston, C.A.

1999 The Script of Hebrew Ostraca of the Iron Age: $8^{\text {th }}-6^{\text {th }}$ Centuries BCE (Ph.D. dissertation, John Hopkins University).

2003 'Non-Provenanced Epigraphies I: Pillaged Antiquities, Northwest Semitic Forgeries, and Protocols for Laboratory Tests', Maarav 10: 135-94.

2004 'Non-Provenanced Epigraphies II: The Status of the Non-Provenanced Epigraphs within the Broader Corpus of Northwest Semitic', Maarav 11: 57-79.

2006 'Scribal Education in Ancient Israel: The Old Hebrew Epigraphic Evidence', BASOR 344: $47-74$.

2008 'The Phoenician Script of the Tel Zayit Abecedary and Putative Evidence for Israelite Literacy', in R.E. Tappy and P.K. McCarter (eds.) Literate Cultures and Tenth-Century Canaan: The Tel Zayit Abecedary in Context (Winona Lake, In.: Eisenbrauns) 61-96.

2010 Writing and Literacy in the World of Ancient Israel: Epigraphic Evidence from the Iron Age (Atlanta: SBL). 
Sanders, S.L.

2009 The Invention of Hebrew (Chicago: University of Illinois Press).

Sarna, N.M.

2007 'Bible; The Canon, Text, and Editions', in M. Berenbaum and F. Skolnik (eds.)

Encyclopaedia Judaica (Detroit: Macmillan Reference USA, 2nd edn [1971]) 3: 572-679.

Schams, C.

1998 Jewish Scribes in the Second-Temple Period (JSOTSup, 291; Sheffield: Sheffield Academic Press).

Schniedewind, W.M.

1999 'Qumran Hebrew as an Antilanguage', JBL 118: 235-52.

2004 How the Bible Became a Book: The Textualization of Ancient Israel (Cambridge:

Cambridge University Press).

Snell, D.C.

1993 Twice-Told Proverbs and the Composition of the Book of Proverbs (Winona Lake, Ind.: Eisenbrauns).

Tadmor, H.

1991 On the Role of Aramaic in the Assyrian Empire, in M. Mori, Hi. Ogawa and M. Yoshikawa (eds.) Near Eastern Studies Dedicated to H.I.H. Prince Takahito Mikasa On the Occasion of His Seventy-Fifth Birthday (BMECCJ, 5; Wiesbaden: Harrassowitz) 419-26. 
Toorn, K. van der,

2007 Scribal Culture and the Making of the Hebrew Bible (Cambridge, Ma.: Harvard University Press).

Weinfeld, $M$.

1972 Deuteronomy and the Deuteronomic School (Oxford: Clarendon).

Wheeler Robinson, $\mathrm{H}$.

1981 Corporate Personality in Ancient Israel (repr.; Edinburgh: T\&T Clark [1935]).

Young, I.M.

1993 Diversity in Pre-Exilic Hebrew (FAT, 5; Tübingen: Mohr Siebeck). 
Abbreviations

4QSam ${ }^{\mathrm{a}} \quad$ Samuel scroll found in cave 4 at Qumran

BASOR Bulletin of the American Schools of Oriental Research

BMECCJ Bulletin of the Middle Eastern Culture Center in Japan

BIL The British Encyclopaedia Library

FAT Forschungen zum Alten Testament

JBL Journal of Biblical Literature

JCS Journal of Cuneiform Studies

JSOT Journal for the Study of the Old Testament

JSOTSup Journal for the Study of the Old Testament, Supplement Series

LXX Septuagint

MT Masoretic Text

OBO Orbis Biblicus et Orientalis

SBL Society of Biblical Literature

SBT Studies in Biblical Theology

UUÅ Uppsala universitets årsskrift

VT Vetus Testamentum

VTSup Vetus Testamentum, Supplement Series 